\title{
PENERAPAN BUDAYA KERJA 5R/5S DAN PENGARUHNYA TERHADAP KINERJA KARYAWAN DI CV. CAHAYA MANDIRI
}

\author{
Sofiyanurriyanti, Ahmad Isti'dzan As Shofi \\ Program Studi Teknik Industri \\ Sekolah Tinggi Teknik Qomaruddin Gresik \\ Jln. Raya Bungah No. 01, Kecamatan Bungah, Bungah, \\ Kabupaten Gresik, (031) 3943999 \\ Sofiyanurriyanti20@gmail.com
}

\begin{abstract}
Abstrak
$\mathrm{P}$ enelitian ini bertujuan untuk mempengaruhi kinerja karyawan di perusahaan dan pengaruh busaya kerja $5 \mathrm{R}$ terhadap kinerja karyawan di CV. CAHAYA MANDIRI. Perusahaan CV. CAHAYA MANDIRI adalah perusahaan yang bergerak pada bidang jasa. Hal itulah yang membuat alat penunjang begitu diperlukan saat melakukan pekerjaan. Pada saat alat penunjang tersebut hilang atau lupa tempat ditaruhnya maka akan berpengaruh besar terhadap kinerja perusahaan. Perusahaan tidak akan dapat bekerja dengan maksimal dikarenakan adanya masalah terhadap alat penunjang tersebut. Jika masalah tersebut dapat diatasi maka perusahaan tidak akan mengalami masalah dan kinerja perusahaan akan menjadi maksimal. Metode penelitian ini dilakukan dengan metode kualitatif dan kuantitatif. Pengambilan data sampel yang digunakan dalam penelitian ini adalah karyawan CV. CAHAYA MANDIRI dimana terdapat 50 (lima puluh) jumlah karyawan di perusahaan, dalam analisis penelitian ini dilakuakan dengan menggunakan sampel sebanyak 10 (sepuluh) responden secara random sampling pada karyawan perusahaan. Faktor yang mempengaruhi untuk mengetahui budaya kerja $5 \mathrm{R} / 5 \mathrm{~S}$ terhadap kinerja karyawan. Nilai koefisien korelasi berganda menunjukkan angka sebesar $R^{2}(0,739)$ atau $73,9 \%$ yang berarti kegiatan $5 \mathrm{R} / 5 \mathrm{~S}$ dalam perusahaan bisa mempengaruhi kinerja karyawan sebesar 73,9\%, sisanya sebesar 26,1\% dipengaruhi oleh variabel lain diluar kegiatan 5R/5S. Budaya 5R/5S sangat bagus diterapkan dalam sebuah perusahaan. Dari data tersebut diperoleh hasil persamaan Regresi Linier sebagai berikut : Kinerja $(\mathrm{Y})=6,336+1,007$ ringkas $(\mathrm{X} 1)+0,038$ rapi $(\mathrm{X} 2)+0,359$ resik $(\mathrm{X} 3)+0,344$ rawat $(\mathrm{X} 4)+$ 0,098 rajin (X5).
\end{abstract}

Kata Kunci : Kinerja, 5S/5R, Sistem Manufaktur

\section{PENDAHULUAN}

Perkembangan teknologi saat ini semakin maju dan canggih dengan beberapa inovasi baru yang ada dikehidupan sehari-hari. Perubahan kemajuan industri ini juga memberikan manfaat positif baik dibidang manufaktur atau jasa sehingga dapat dinikmati oleh banyak kalangan pihak (Kristanto, 2009).Perubahan dunia industri juga mempengaruhi banyak tuntutan kerja yang diiginkan suatu perusahaan untuk mendukung pekerjaan yang dilakukan agar lebih nyaman dan lebih mudah dijangkau. Globalisasi perusahaan saat ini begitu cepat dalam meningkatan kebutuhan perusahaan namun apabila perusahaan tersebut tidak mampu dalam bersaing maka otomatis perusahaan tersebut tidak mampu melanjutkan usahanya dalam bersaing dalam meningkatkan barang atau produk dengan kualitas internasional (Seng, 2007). Industri- industri baru juga semakin banyak yang bermunculan, dimana perusahan dituntut mampu menjadi lebih unggul, bermutu dan mampu bersaing menghadapi persaingan. Selain itu dengan karyawan juga dapat termotivasi dalam bekerja dengan memberikan yang lebih baik di perusahaan. Penerapan 5S ini dapat meminimalkan kegiatankegiatan yang dapat memberikan nilai tambah terhadap lingkungan sekitar seperti menyiapkan peralatan dan bahan, mencari peralatan, mengambil peralatan, menyimpan barang, memproduksi serta menunggu saat akan delay atau proses dan sebagainya. Kegiatan tersebut dapat memberikan nilai tambah dan terciptalah tempat produksi yang efektif dan efisien. 


\section{TINJAUAN PUSTAKA \\ Budaya Kerja 5R atau 5S}

S5 dalam bahasa Indonesia disebut sebagai 5R antara lain (Ringkas, Rapi, Resik, Rawat, Rajin). Menurut Kristaianti (2000) 5R atau 5S merupakan dasar awal baru untuk peningkatan ringkat produktivitas dan kemampuan perusahaan dalam bersaing dari langkah awal sampai langkah akhir untuk menjadi industri maju. Sedangkan menurut Program 5S merupakan suatu metode didalam pengelolaan lingkungan yang bersih yang diwajibkan oleh manajemen perusahaan dan djalankan oleh setiap karyawan. Program 5S ini bertujuan untuk menciptakan lingkungan kerja yang bersih, nyaman, rapai, sehat dan dapat tertata indah sehingga dapat memberikan keselamatan kerja karyawan terjamin. Budaya 5S merupakan salah satu standarisasi prosedur kerja terhadap lingkungan kerja, yang membuat karyawan

Penerapan budaya kerja 5R/5S menurut Tanson, 2011 dalam penelitiannya yang dilakukan dengan melakukan penambahan satu elemen yaitu elemen safety dengan tujuan menciptakan lingkungan kerja yang ringkas, rapi, resik rawat dan rajin dengan memperhatikan aspek dari keselamatan kerjanya. Sedangkan Yunita, 2007 yang berjudul perancangan dan implementasi $5 \mathrm{~S}$ di Univeritas $\mathrm{X}$ memiliki tujuan untuk memperbaiki budaya kerja dengan adanya dukungan dan komitmen dari seluruh pihak kalangan kampus yang ada.

\section{Konsep 5S}

5S berasal dari bahasa Jepang yang diawali dengan huruf "S". Konsep 5S ini merupakan konsep yang sederhana yang menerapkan budaya tentang seseorang di tempat kerjanya dimana terdapat tertata rapi, bersih, tertib.

Tujuan dan manfaat $5 \mathrm{~S}$ dari penerapan diantaranya adalah menurunkan pemborosan waktu, dapat memperbaiki kondisi fisik area kerja dan tempat kerja, meningkatkan kinerja, produktivitas dan efisiensi bekerja, menurunkan tingkat kerusakan produk dan alat produksi yang dilakukan, serta dapat menurunkan tingkat resiko kecelakaan yang ada di area lokasi bekerja dan dapat memuwujudkan perusahaan bersifat positif di kalangan masyarakat maupun pelanggan.

\section{METODE PENELITIAN}

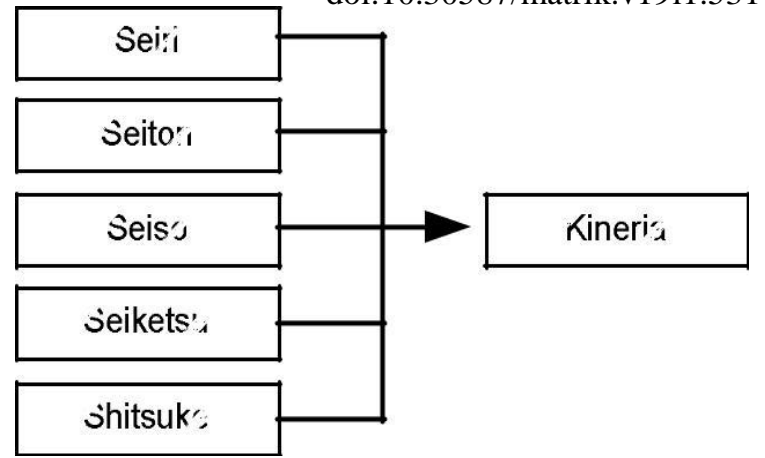

Gambar 1. Kerangka pikir

H1. Variabel budaya kerja 5R/5S (seiri, seiton, seiso, seiketsu, shitsuke) secara parsial berpengaruh signifikan terhadap kinerja karyawan

$\mathrm{H} 2$. Variabel budaya kerja 5R/5S (seiri, seiton, seiso, seiketsu, shitsuke) secara simultan berpengaruh signifikan terhadap kinerja karyawan

Penelitian ini dilakukan dalam bentuk survey, dengan menggunakan pendekatan explanation research atau penelitian penjelasan yaitu penelitian yang menjelaskan hubungan kausal antara variabelvariabel melalui pengujian hipotesis Singarimbun, (1989) serta dengan survey yaitu sampel yang diambil dari suatu populasi dan menggunakan kuesioner sebagai alat pengumpulan data yang pokok dan pada umumnya merupakan unit analisis individua, sampel yang digunakan dalam penelitian ini adalah karyawan CV. CAHAYA MANDIRI dimana terdapat 50 (lima puluh) jumlah karyawan di perusahaan, dalam analisis penelitian ini dilakuakan dengan menggunakan sampel sebanyak 10 (sepuluh) responden secara random sampling pada karyawan perusahaan.

Tabel 1. Variabel dan Definisi operasional

\begin{tabular}{|c|l|}
\hline Variabel & Definisi operasional \\
\hline $\begin{array}{c}\text { Seiri } \\
(X 1)\end{array}$ & $\begin{array}{l}\text { Kegiatan pemilahan yang dilakukan } \\
\text { oleh karyawan }\end{array}$ \\
\hline $\begin{array}{c}\text { Seiton } \\
(\mathrm{X} 2)\end{array}$ & $\begin{array}{l}\text { Kegiatan penataan yang dilakukan oleh } \\
\text { karyawan }\end{array}$ \\
\hline Seiso & Kegiatan pembersihan yang dilakukan \\
$(\mathrm{X} 3)$ & oleh karyawan \\
\hline Seiketsu & Kegiatan pemantapan yang dilakukan \\
$(\mathrm{X} 4)$ & oleh karyawan \\
\hline Shitsuke & Kegiatan pembiasaan yang dilakukan \\
$(\mathrm{X} 5)$ & oleh karyawan \\
\hline
\end{tabular}


Volume XIX No.1, September 2018, p 1-7

\begin{tabular}{|c|l|}
\hline $\begin{array}{c}\text { Kinerja } \\
(\mathrm{Y})\end{array}$ & $\begin{array}{l}\text { Hasil kerja yang dihasilkan oleh seorang } \\
\text { karyawan yang diukur melalui kualitas, } \\
\text { kuantitas, waktu kerja, dan kerjasama }\end{array}$ \\
\hline
\end{tabular}

\section{HASIL DAN PEMBAHASAN}

Pengumpulan data kuesioner didapatkan dari penyebaran kuisioner terhadap 10 karyawan yang bekerja dengan menggunakan 5 variabel yaitu ringkas, rapi, resik, rawat dan rajin.

Tabel 2. Data kuesioner yang diambil dari karyawan di CV. CAHAYA MANDIRI

\begin{tabular}{|c|c|c|c|c|c|c|}
\hline $\begin{array}{c}\text { Respon } \\
\text { den }\end{array}$ & Ringkas & Rapi & Resik & Rawat & Rajin & $\begin{array}{c}\text { Kine } \\
\text { rja }\end{array}$ \\
\hline Aris & 4 & 5 & 3 & 3 & 5 & 3 \\
\hline Ari & 2 & 3 & 3 & 4 & 3 & 4 \\
\hline Doni & 3 & 4 & 4 & 3 & 3 & 4 \\
\hline Eko & 3 & 4 & 2 & 3 & 3 & 3 \\
\hline Wiji & 4 & 3 & 3 & 2 & 5 & 3 \\
\hline Fajar & 3 & 3 & 2 & 3 & 3 & 3 \\
\hline $\begin{array}{l}\text { Kholi } \\
\text { k }\end{array}$ & 5 & 4 & 3 & 2 & 4 & 2 \\
\hline $\begin{array}{l}\text { Ghop } \\
\text { ur }\end{array}$ & 3 & 4 & 2 & 3 & 3 & 3 \\
\hline $\begin{array}{l}\text { Idho } \\
\text { m }\end{array}$ & 4 & 4 & 4 & 4 & 4 & 2 \\
\hline Ryo & 3 & 3 & 3 & 4 & 3 & 4 \\
\hline
\end{tabular}

Data diatas akan diolah dan dianalisis dengan menggunakan bantuan software SPSS for windows 23.0 .

\section{Pengolahan data \\ Pengujian Hipotesis}

Hipotesis 1 adalah menguji hubungan parsial antara variabel budaya $5 \mathrm{~S}$ terhadap Kinerja Karyawan. Dari hasil olah data yang dilakukan dengan software SPSS diperoleh hasil sebagai berikut:

Tabel 3. Hasil Uji T

\begin{tabular}{lcccc} 
Model & $\begin{array}{c}\text { Unstan } \\
\text { dardize } \\
\text { d }\end{array}$ & $\begin{array}{c}\text { Standa } \\
\text { rdized } \\
\text { Coeffici }\end{array}$ & t & Sig \\
\hline
\end{tabular}

e-ISSN : 2621-8933 p-ISSN : 1693-5128

doi:10.30587/matrik.v19i1.531

ents

\begin{tabular}{|c|c|c|c|c|c|}
\hline & B & $\begin{array}{l}\text { Std. } \\
\text { Error }\end{array}$ & Beta & & \\
\hline Constant & 6.336 & 1.919 & & 3.301 & .030 \\
\hline Ringkas & -1.007 & .397 & -1.150 & -2.538 & .064 \\
\hline Rapi & -0.38 & .314 & -034 & -.120 & .910 \\
\hline Resik & .359 & .310 & .359 & 1.158 & .311 \\
\hline Rawat & -.344 & .377 & -344 & -.914 & 413 \\
\hline Rajin & .098 & .331 & .112 & .297 & .781 \\
\hline
\end{tabular}

Data tersebut kriteria yang dilakukan adalah dengan membandingkan $\mathrm{T}$ hitung dengan $\mathrm{T}$ tabel, apabila $\mathrm{T}$ hitung lebih besar dari tabel maka asumsinya terpenuhi atau dengan membandingkan nilai Sig. T tingkat kesalahan yang digunakan dalam penelitian ini yaitu sebesar 0,5. Apabila nilai sig T lebih kecil dari 0,5 berarti secara parsial variabel $5 \mathrm{R} / 5 \mathrm{~S}$ berpengaruh terhadap kinerja karyawan, namun bila nilai sig $\mathrm{T}$ lebih besar dari 0,5 berarti tidak signifikan. Dari hasil diatas menunjukkan bahwa secara parsial terdapat dua variabel yang tidak signifikan terhadap kinerja karyawan yaitu variabel rapi dengan nilai sig $\mathrm{T}$ sebesar 0,9 dan rajin dengan nilai sig $\mathrm{T}$ sebesar 0,7 dimana lebih besar 0,5. Sedangkan variabel yang lain secara parsial berpengaruh signifikan terhadap kinerja karyawan.

\section{a. Pengujian Hipotesis 2}

Hipotesis 2 adalah menguji hubungan simultan antara variabel budaya $5 \mathrm{~S}$ terhadap Kinerja Karyawan. Dari hasil olah data yang dilakukan dengan software SPSS diperoleh hasil sebagai berikut:

Tabel 4. Hasil uji F

\begin{tabular}{llcccc}
\hline \multicolumn{1}{c}{ Model } & $\begin{array}{c}\text { Sum of } \\
\text { Squares }\end{array}$ & df & $\begin{array}{c}\text { Mean } \\
\text { Square }\end{array}$ & F & Sig \\
\hline Regression & 3.619 & 5 & .724 & 2.260 & $.225 \mathrm{~b}$ \\
\hline Residual & 1.281 & 4 & .320 & & \\
\hline Total & 4900 & 9 & & & \\
\hline
\end{tabular}

Data tersebut menunjukkan bahwa secara simultan variabel budaya $5 \mathrm{R} / 5 \mathrm{~S}$ tidak signifikan terhadap Kinerja Karyawan. Secara bersama-sama variabel ringkas, resik, rapi, rawat, rajin berpengaruh terhadap Kinerja Karyawan. Kriteria tersebut ditunjukkan dengan nilai $\mathrm{F}$ sebesar 2.260 dimana 33 nilai Fhitung tersebut lebih besar dari nilai Ftabel, 33 atau dengan membandingkan nilai Sig.F dengan 
Jurnal MATRIK

Volume XIX No.1, September 2018, p 1-7

tingkat kesalahan yang digunakan dalam penelitian ini yaitu sebesar 0,5. Apabila nilai sigF lebih kecil dari 0,5 berarti secara bersama-sama variabel $5 \mathrm{R} / 5 \mathrm{~S}$ tidak berpengaruh terhadap kinerja karyawan. Variasi pengaruh sebesar $R^{2}(0,739)$ atau $73,9 \%$.

\section{Tabel 5. Hasil Uji R}

\begin{tabular}{ccccc}
\hline Model & $\mathbf{R}$ & $\begin{array}{c}\mathbf{R} \\
\text { Square }\end{array}$ & $\begin{array}{c}\text { Adjusted } \\
\mathbf{R} \\
\text { Square }\end{array}$ & $\begin{array}{c}\text { Std. } \\
\text { Error of } \\
\text { the } \\
\text { Estimate }\end{array}$ \\
\hline 1 & $.859^{\mathrm{a}}$ & .739 & .412 & .56588 \\
\hline
\end{tabular}

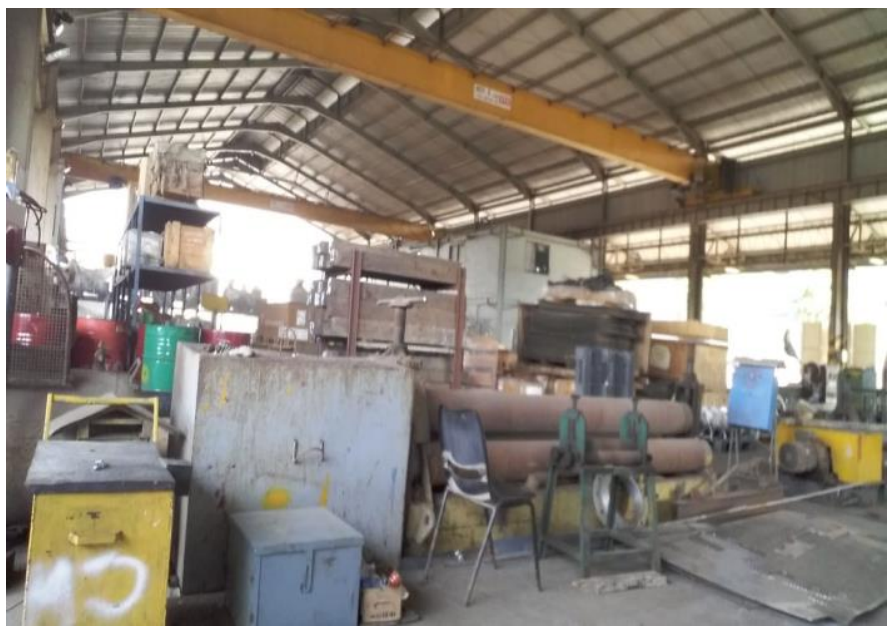

Gambar 2. Lokasi Tempat Kerja (Workshop)

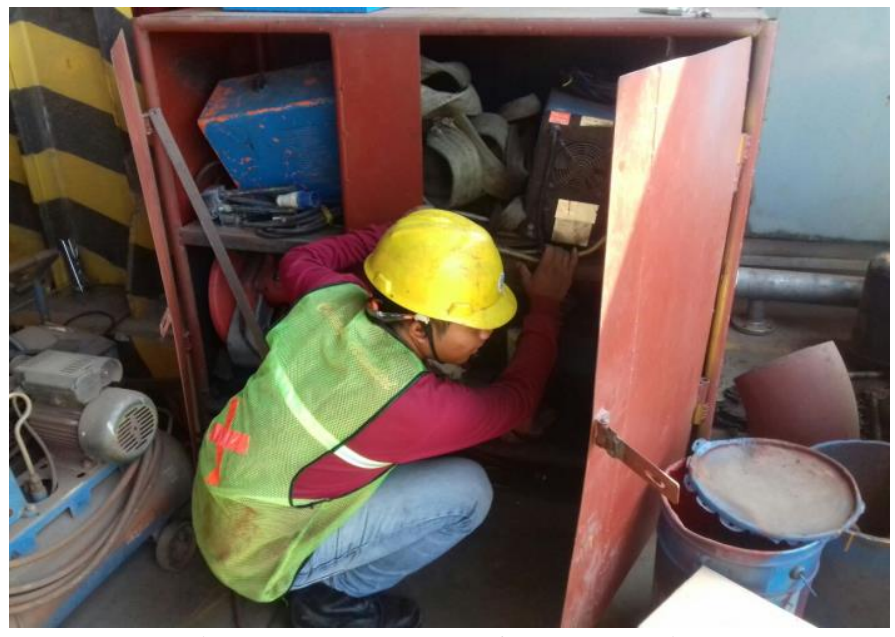

Gambar 3. Tempat Penyimpanan Alat 1
e-ISSN : 2621-8933 p-ISSN : 1693-5128

doi:10.30587/matrik.v19i1.531

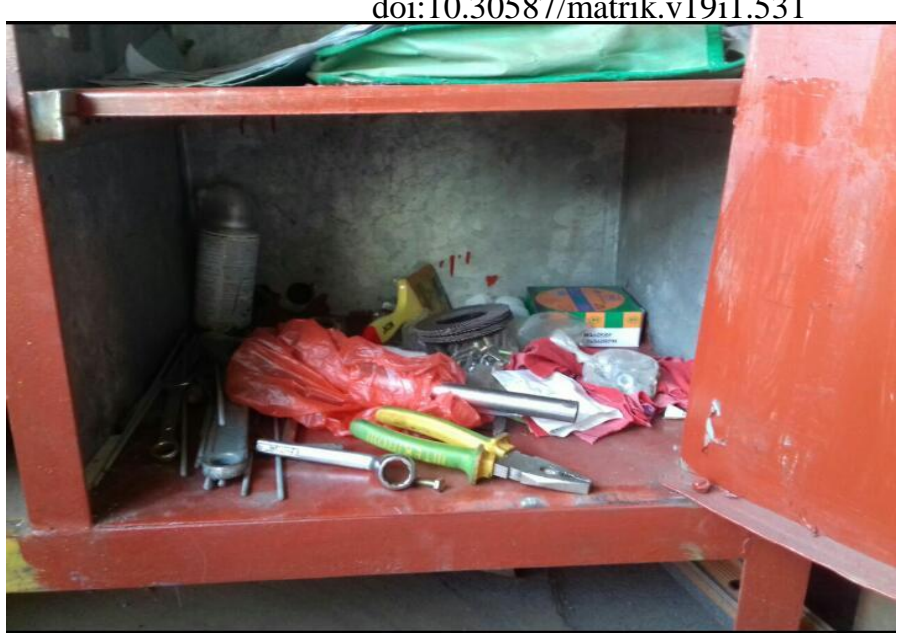

Gambar 4. Alat-alat sebelum dirapikan

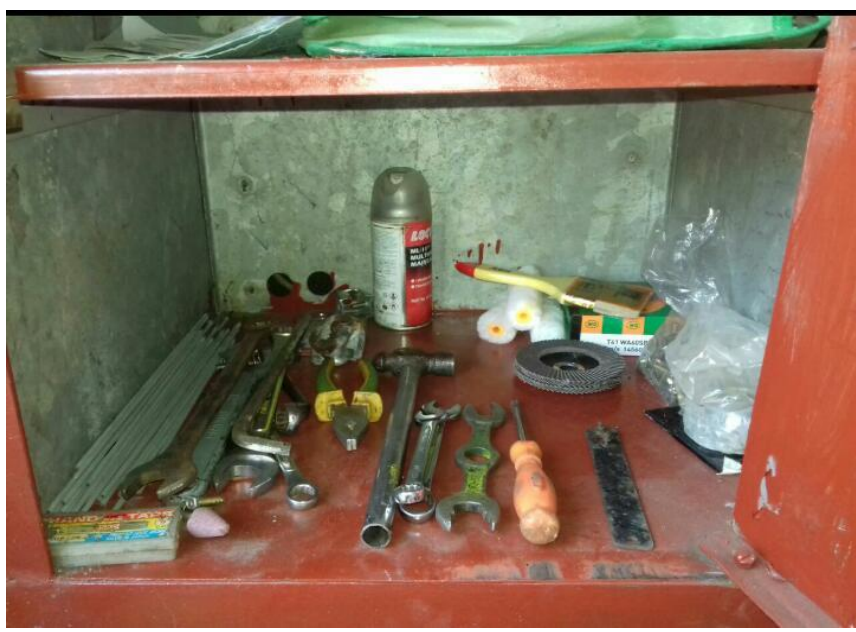

Gambar 5. Alat-alat sesudah dirapikan

\section{KESIMPULAN}

Kesimpulan pada penelitian sebagai berikut :

1. Faktor yang mempengaruhi untuk mengetahui budaya kerja 5R/5S terhadap kinerja karyawan. Nilai koefisien korelasi berganda menunjukkan angka sebesar $R^{2}(0,739)$ atau $73,9 \%$ yang berarti kegiatan $5 \mathrm{R} / 5 \mathrm{~S}$ dalam perusahaan bisa mempengaruhi kinerja karyawan sebesar $73,9 \%$, sisanya sebesar $26,1 \%$ dipengaruhi oleh variabel lain diluar kegiatan $5 \mathrm{R} / 5 \mathrm{~S}$. Budaya $5 \mathrm{R} / 5 \mathrm{~S}$ sangat bagus diterapkan dalam sebuah perusahaan.

2. Budaya Kerja $5 \mathrm{R} / 5 \mathrm{~S}$ yang meliputi ringkas/Seiri (Pemilahan), resik/Seiton (Penataan), rapi/Seiso (Pembersihan), rawat/Seiketsu (Pemantapan) dan rajin/Shitsuke (Pembiasaan) yang diterapkan di perusahaan secara bersama-sama bisa mempengaruhi kinerja karyawan. 


\section{DAFTAR PUSTAKA}

Aditya, agung (2011), pengaruh konpensasi dan budaya kerja terhadap kinerja karyawan pada PT. Barutama unit offset kudus,, fakultas ekonomi Universitas Diponegoro Semarang.

Ambar Yunaidi, (2014), profil perusahaan CV CAHAYA MANDIRI : Gresik jawa timur.

Brahmasari, Ida, Ayu, (2004), Pengaruh variabel budaya perusahaan terhadap komitmen karyawan dan kinerja perusahaan kelompok penerbitan jawa pos, Universitas Airlangga, Surabaya.

Firdaus, Faizuddin, (2005), Analisa pengaruh budaya perusahaan jepang terhadap pengaruh kerja karyawan, Tesis, program studi magister manajemen program pascasarjana, Universitas 17 Agustus 1945 Surabaya

Ruky, Achmad S, (2002), Sistem Manajemen Kinerja (performance manageement system), cetakan kedua, PT. Gramedia Pustaka Utama : Jakarta.

Seng, Ann Wan, (2007), Rahasia Bisnis Orang Jepang (Langkah Raksasa sang Nippon Menguasai Dunia), Hikmah PT. Mizan Publika :Jakarta.

Setiawan S, Iwan, (2004), Budaya Manajemen Jepang Membangun Produktifitas Kerja, Elex Media Computindo : Jakarta. 
Jurnal MATRIK

Volume XIX No.1, September 2018, p 1-7

(Halaman ini sengaja dikosongkan)
e-ISSN : 2621-8933 p-ISSN : 1693-5128

doi:10.30587/matrik.v19i1.531 